This is an electronic reprint of the original article. This reprint may differ from the original in pagination and typographic detail.

Author(s): Rönkkö, Mikko; Ojala, Arto; Tyrväinen, Pasi

Title: Innovation as a Driver of Internationalization in the Software Industry

Year: $\quad 2013$

Version:

Please cite the original version:

Rönkkö, M., Ojala, A., \& Tyrväinen, P. (2013). Innovation as a Driver of Internationalization in the Software Industry. In IEEE 3rd International Conference on Research and Innovation in Information Systems (pp. 49-54). IEEE Conference Proceedings. International Conference on Research and Innovation in Information Systems. https://doi.org/10.1109/ICRIIS.2013.6716684

All material supplied via JYX is protected by copyright and other intellectual property rights, and duplication or sale of all or part of any of the repository collections is not permitted, except that material may be duplicated by you for your research use or educational purposes in electronic or print form. You must obtain permission for any other use. Electronic or print copies may not be offered, whether for sale or otherwise to anyone who is not an authorised user. 


\section{Innovation as a Driver of Internationalization in the Software Industry}

\author{
Mikko Rönkkö \\ Aalto University \\ Helsinki, Finland \\ mikko.ronkko@aalto.fi
}

\author{
Arto Ojala \\ University of Jyväskylä \\ Jyväskylä, Finland \\ arto.k.ojala@jyu.fi
}

\author{
Pasi Tyrväinen \\ University of Jyväskylä \\ Jyväskylä, Finland \\ pasi.tyrvainen@jyu.fi
}

\begin{abstract}
Innovation and internationalization are two important factors for growth. This study analyzes whether innovativeness has an effect on the internationalization of software firms, and if so, how strong this effect is. Innovation and internationalization have rarely been studied together, with research tending to focus more on the relationship between innovations and growth. However, internationalization is a key prerequisite for growth for companies operating in small domestic markets. This paper analyzes the innovativeness and internationalization of firms, using data from the Software Industry Survey conducted in Finland. Since the speed of firm growth and internationalization are dependent on the willingness to grow and the age of the firm, these variables are used as moderators in the analysis. Our analysis suggests that innovativeness does contribute to internationalization; however, the effect is significant only for younger firms during their expansion to new markets, after which they prioritize revenue growth.
\end{abstract}

Keywords: Innovativeness, internationalization, growth, software firms

\section{INTRODUCTION}

Innovations and innovativeness are crucial for competitiveness and economic growth. Furthermore, innovations are an important source of competitive advantage for firms operating in international markets [37]. Several studies have also found that the innovativeness of a firm is positively related to the speed of internationalization $[8,9,12,22]$. The software industry is characterized by innovation-driven market growth [30]. Broadly speaking, one can say that the software industry contributes to the economy in two ways. First of all, software can be used to increase productivity in other industries. Secondly, software can be sold abroad, generating export revenue. While the impact of software innovations on productivity has been extensively investigated (e.g. [10,5]), the effect of software innovations on internationalization remains a somewhat understudied topic [12]. This is surprising, since the internationalization of software firms has attracted considerable attention in academic literature (e.g. $[6,14,15$, $27,29,31,32,33])$. Moreover, young high-growth firms have been shown to have a strong impact on economic development [1,27], and for companies with small domestic markets, internationalization can be regarded as a natural stage in development [40]. It appears that studying the effect of innovativeness on internationalization could help us to understand how small firms can generate growth. The aim of this paper is thus to address the innovativeness of software firms from an internationalization perspective, via an analysis of firm internationalization as a function of a firm's age, its innovativeness, and its willingness to grow.

\section{THEORETICAL BACKGROUND AND DEVELOPMENT OF HYPOTHESES}

The internationalization process of a firm can be studied from two distinct perspectives. The first and more traditional view of internationalization is encapsulated in the Uppsala model of internationalization, developed by Johanson and Wiedersheim-Paul [21] and by Johanson and Vahlne [19]. The second and more recent model is embodied in the International New Venture (INV) theory developed by Oviatt and McDougall [34]. The underlying assumptions of and differences between these theories are explained briefly below.

The Uppsala model describes internationalization as an incrementally evolving process, in which a firm internationalizes its operations in various stages. In this model, a firm's internationalization is based on increasing market knowledge, which increases market commitment through commitment decisions and current activities [19]. According to the model, firms operate first in their domestic markets and only thereafter start to internationalize, initially entering into nearby markets (markets that share a similar language, culture, political system, level of education, level of industrial development, and so on). After that, when a firm's knowledge of international operations increases, it gradually starts to develop activities in more distant countries. Thus, knowledge of and learning about foreign markets has a central role. The model divides knowledge into general knowledge and market-specific knowledge. General knowledge is objective, and transferable from previous countries entered to the target country. It includes general issues concerning marketing methods, operation modes, and typical customers, on a global scale. Marketspecific knowledge is based on previous experiences of the target country environment, including its culture, the market structure, the customers in the market, and so on. This knowledge is mainly acquired through operating in the target country [19].

Recent studies on new ventures and "born globals" have challenged the internationalization process described in the Uppsala model [7, 22, 28, 34], and have proposed 


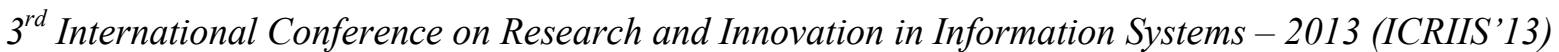

alternative internationalization pathways [7, 23, 26]. The study by Oviatt and McDougall mentioned above [34] gave a theoretical foundation for why some firms internationalize faster than traditional internationalization theories would predict. INV theory is based on the notion that the internationalization of INVs is related to opportunityseeking behavior, according to which an INV "seeks to derive significant competitive advantage from the use of resources and the sale of outputs in multiple countries" [34: 49]. The theory proposes that the origins of an INV are international because they have commitments to valuable resources in more than one country. Within the theory, "international from the inception" means that the founders of an INV seek growth opportunities in foreign markets, and have already made some decisions related to the international scope of these activities, before foundation of the firm [28, 34]. This perspective places an emphasis on firms whose products are innovative and perhaps new on a global scale. Such firms tend to exist in high-technology sectors. One of the premises of the theory concerning INVs is that a firm must control unique and non-imitable resources, capable of creating competitive advantage [4] internationally. INVs must also have the capability to transfer and combine mobile resources with less mobile ones in the target countries, in order to generate value. Software can be considered a prime example of this kind of resource, and it is created through innovation.

Although innovativeness is often believed to be one of the leading drivers of growth [11], the evidence supporting this belief is far from conclusive. This uncertainty is due to difficulties in operationalizing innovativeness and also to the complexity of the relationship between innovativeness and growth on the level of individual firms [13]. Two characteristics of innovations make it difficult to study. First of all, innovations tend to not to carry over into sales growth until several years have elapsed. This is due to the fact that innovations do not immediately result in revenue; they must be further developed into products or services, and these often require manufacturing or other production processes. Secondly, not all innovations survive the test of the market, and they may well fail to generate increases in revenue. However, one persistent finding is that firms which innovate and grow seem to grow more rapidly than non-innovative firms [18]. This would suggest that successful innovations do indeed promote growth at the firm level.

For firms operating in high-technology sectors with small home markets, internationalization is often considered a natural step in the life-cycle of the firm (cf. [7, 24]). The software industry is in many ways an atypical industry in terms of international expansion. For instance, software companies can use the Internet to distribute their products, giving them instant access to global markets. Furthermore, the ability to distribute digital goods with minimum marginal costs is a unique characteristic of the software industry. It is notable that many software companies actually achieve their first international sales before domestic sales. This is particularly the case with providers of specialized systems and applications in business-to- business markets. Due to these various characteristics, the internationalization of software firms has also received a considerable amount of attention in academic circles, as demonstrated by the proliferation of studies addressing the internationalization of software firms in particular $[6,14$, $15,32,33,36,43]$.

Since innovativeness is often studied in the context of growth, and since growth is often linked to internationalization, it is surprising that only a few studies have linked these three phenomena (e.g. $[8,22])$. Of the two internationalization models presented briefly above, only the INV model explicitly addresses innovations; for its part, the traditional model either ignores this or presents it as a phenomenon embedded in the broader context of resource acquisition. Nevertheless, since innovativeness is clearly a positive determinant of growth, and since in countries with small home markets growth often takes place through international expansion, we can formulate the following hypothesis:

Hypothesis 1: The innovativeness of software firms increases the probability of internationalization.

However, there is evidence that not all innovative firms grow. In a study related to the Finnish software industry, Rönkkö et al. [39] found that willingness to grow was among the most significant determinants of both growth and internationalization. INV theory emphasizes that rapidly internationalizing new ventures actively seek opportunities and growth possibilities in foreign markets [34]. However, it further appears that some small firms prioritize innovation and technological tinkering over expansion of the business; they have little desire to grow, believing that this would restrict the freedom of their employees to experiment with new technologies. For these reasons, one could expect willingness to grow to have a positive effect on the relationship between innovativeness and growth. Such a chain of reasoning leads to our next hypothesis:

Hypothesis 2: Willingness to grow positively moderates (increases) the effect of software firm innovativeness on the probability of internationalization.

In INV theory, the young age of a firm is emphasized; thus, firms that follow the INV model tend to start foreign sales either right at the inception of the firm or very soon afterwards, during the first years of their operations [3, 34]. Firms that rely more on innovations than on resource accumulation (cf. [19]) in preparing for international expansion tend to internationalize early, and this has an effect on the overall internationalization phenomenon. The overall line of argument here includes the notion that innovative firms tend to internationalize early, and hence that innovativeness is less likely to have a major role among firms that internationalize later. Hence we can expect the two relationships presented earlier to be conditional on the age of the firm, giving us the following hypotheses: 


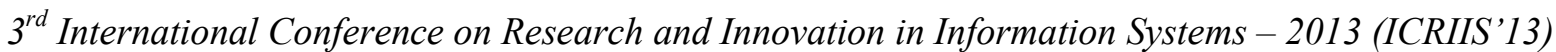

Hypothesis 3: The effect of innovativeness on the probability of internationalization is stronger for younger software firms than for older software firms.

Hypothesis 4: The moderating effect of willingness to grow on the association between innovativeness and internationalization will be more pronounced for younger software firms than for older software firms.

\section{RERSEARCH DESIGN}

\section{A. Sample}

The present paper uses data collected from the Finnish software industry over the years 2008 and 2009. The details of the sampling frame have evolved over the years to match the changing needs of the survey. NACE codes 7221 ("Publication of software") and 7222 ("Other software consultancy and supply") have typically been included. To cover the entire software industry, including also firms officially registered under other industry codes, the sampling frame included the member lists of several industry associations. The reason for this approach is that the trade register data is considered to cover the software industry only partially, since some companies have software as a secondary industry. In addition, the survey project during which the data were collected required that the entire industry should be covered. Typically, the sampling frame covered all firms with five or more people, and smaller enterprises only if they were members of some industry association, or if they had registered on any of the lists covering the software industry (these lists include, for example, a list of software companies that had applied for product development subsidies from public organizations). However, the coverage of the smallest firms varies between years. It should also be noted that missing revenue data were obtained later from Asiakastieto Ltd., which collects and organizes information from the publicly accessible Finnish trade register.

\section{B. Constructs and measures}

The dependent variable "has international revenue" was measured via a self-report in the survey. The question asked whether the firm had international revenues, and the response options were as follows: (1) Yes; (2) No, but we have considered internationalization; (3) No, international business is not relevant to us at present. The first option was coded as a positive answer, and the other two as negative.

The methodological challenges in measuring innovations relate to the weaknesses of $R \& D$ intensity and patenting as indicators of innovativeness. Both of these indicators have been criticized in the literature [35, 41]. Moreover, both apply better to larger firms than to small entrepreneurial firms. With this in mind, we used a self- reporting scale to measure innovativeness. We adapted three items measuring innovativeness from a widely used Entrepreneurial Orientation Scale [16, 25]. Cronbach's alpha reliability coefficient was .69 , and principal factor analysis indicated discriminant validity.

Willingness to grow was measured via a self-developed scale. The full scale consists of eight items measuring three dimensions of attitude towards growth: general willingness to grow, tolerance of risk to achieve growth, and willingness to grow internationally. The first three items measured general growth motivation, and the degree to which growth was prioritized over other objectives. For the purposes of this paper we used this dimension as a measure of willingness to grow. Cronbach's alpha reliability coefficient was .87 , and principal factor analysis indicated discriminant validity. We retrieved the firm age from trade register data and then derived the variable age class by splitting this variable at two, five, and ten years to arrive at four age classes (i.e. (i) 0-2, (ii) 2-5, (iii) 5-10, (iv) 10-).

\section{Data collection and analysis}

Loosely following a tailored design in our approach [17], data collection for the survey took place during the late spring and summer, using a paper and web-based questionnaire. For the year 2009 the invitation to participate was sent to 4544 mainly small and medium-sized companies. Since one of the goals of the Software Industry Survey project was to cover the entire industry, this figure represents a significant amount of oversampling to ensure inclusion of all the relevant firms. In all, we estimated that the figure contains approximately $30 \%$ firms that are either not active or do not operate in the software industry. We obtained a total of 584 complete responses using this approach, representing a response rate of approximately $20 \%$ (which is typical for a survey of this kind). Microenterprises produced the most non-responses, so the effective response rate for the firms with meaningful international activities was higher.

Data analysis was carried out using Intercooled Stata, version 11. After organization of the data, which included inspection of the raw data for outliers and calculation of the values of the constructs, we analyzed the data using logistic regression analysis. Four different models were estimated. The first model tested the direct effect of innovativeness on internationalization (Hypothesis 1), while the second model included an interaction term between innovativeness and willingness to grow (Hypothesis 2). The last two models were derived from the first two by adding factorial interactions between age class and the previously tested direct and interaction effects (Hypothesis 3 and Hypothesis 4). All the independent variables were lagged by one year, and we used the lagged version of the dependent variable as a control. In total, 214 cases were included in the analysis.

\section{RESULTS}

Table 1 shows the descriptive statistics and correlations between the study variables. The correlation table does not show anything strikingly untoward, suggesting that regression analysis can safely be used without much concern over collinearity of the independent variables. 


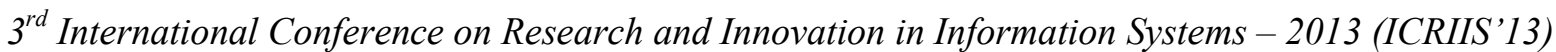

TABLE 1. DESCIPTIVE STATISTICS AND CORRELATIONS

\begin{tabular}{|c|c|c|c|c|c|c|c|}
\hline & & Mean & $\mathrm{SD}$ & 1 & 2 & 3 & 4 \\
\hline 1 & Innovativeness & 0.39 & 1.00 & & & & \\
\hline 2 & Willingness o grow & 0.15 & 0.98 & 9.26 & & & \\
\hline 3 & Willingness o grow $\mathrm{x}$ innovativeness & 0.29 & 1.06 & -9.08 & -9.17 & & \\
\hline 4 & Age & 1.70 & 1.21 & 0.19 & -0.81 & 9.02 & \\
\hline 5 & Has revenue from abroad & 0.38 & 0.49 & 0.16 & 0.17 & 0.07 & 0.14 \\
\hline
\end{tabular}

Table 2 shows the results of the logistic regression analysis. The dependent variable is the binary variable indicating whether the firm has international revenues or not. The lagged version of the same variable is used to control the unmeasured variables and the effect of innovativeness from earlier time periods [1].

\section{TABLE 2. REGRESSION RESULTS}

\begin{tabular}{|c|c|c|c|c|}
\hline & \multicolumn{4}{|c|}{ Has revenue from abroad } \\
\hline & (1) & (2) & (3) & (4) \\
\hline Willingness to grow & 0.24 & 0.22 & & \\
\hline Innovativeness & 0.374 & $0.40 \mathrm{P}$ & & \\
\hline $\begin{array}{l}\text { Has revenue from abroad } \\
\text { Age }=2<2\end{array}$ & $\begin{array}{l}3.60^{* * * x} \\
\text { ref }\end{array}$ & $\begin{array}{l}3.65^{2 * * *} \\
\text { ref }\end{array}$ & $\begin{array}{l}3.96 * 2.4 \\
\text { ref }\end{array}$ & $\begin{array}{l}4.11 * 2 * \\
\text { ref }\end{array}$ \\
\hline Age $-2 \times 5$ & $=0.77$ & -0.75 & $-1.76^{\circ}$ & $-1.89^{*}$ \\
\hline Age $-5 \times<10$ & -0.80 & -0.82 & -0.97 & -1.074 \\
\hline Age $=10$ & -0.39 & -0.39 & -0.61 & -0.56 \\
\hline $\begin{array}{l}\text { Willingness to grow } \mathrm{x} \\
\text { Innovativeness }\end{array}$ & & -0.16 & & \\
\hline Age $=2 \times$ Willingness to grow & & & -0.12 & 0.11 \\
\hline Age $-2<5 \times$ Willingness to grow & & & $1.80^{*}$ & $1.88^{*}$ \\
\hline Age $-5 \times 10 \times$ Willingness to grow & & & $=0.01$ & 0.04 \\
\hline $\begin{array}{l}\text { Age }-\infty 10 \times \text { Willingness to grow } \\
\text { Age }-2 \times \text { Innovativeness }\end{array}$ & & & $\begin{array}{l}0.46 \\
0.80^{*}\end{array}$ & $\begin{array}{l}0.35 \\
0.83^{*}\end{array}$ \\
\hline Age $-2 \times 5 x$ Innovativeness & & & 0.22 & 0.18 \\
\hline Age $-5 \times 10 \times$ Innovativeness & & & 0.62 & 0.76 \\
\hline Age $-10 x$ Innovativeness & & & .0 .25 & 0.31 \\
\hline Age $-<2 \times$ Willingness to grow $x$ Innovativeness & & & -0.21 & \\
\hline $\begin{array}{l}\text { Age }-2 \times 5 \times \text { Willingness to grow } \mathrm{x} \\
\text { Innovativeness }\end{array}$ & & & 0.04 & \\
\hline $\begin{array}{l}\text { Age }-5 \times 10 \times \text { Willingness to grow } x \\
\text { Innovativeness }\end{array}$ & & & $=0.30$ & \\
\hline $\begin{array}{l}\text { Age- } 10 \times \text { Willingness to grow } x \\
\text { Innovativeness }\end{array}$ & & & -0.42 & \\
\hline Intercept & $-1.20=4 x$ & $-1.18 * * *$ & $-1.17 * 0.4$ & $-1.15^{* * 4}$ \\
\hline Observations & 214 & 214 & 214 & 214 \\
\hline $\mathrm{p}$ & 0.00 & 0.00 & 0.00 & 0.00 \\
\hline LR chi2 & 118.58 & 119.20 & 127.74 & 129.70 \\
\hline Pseudo-R2 & 0.40 & 0.41 & 0.44 & 0.44 \\
\hline
\end{tabular}

The pseudo $\mathrm{R}^{2}$ values of each model are high, indicating that the models can accurately explain the dependent variable. However, much of this explanation is due to inclusion of the lagged version of the dependent variable as a predictor. When this is taken into account, one can see that the internationalization actions are affected relatively little by innovativeness or by willingness to grow. Nevertheless, models one and two provide weak support for the hypothesis that innovativeness does indeed promote internationalization at the firm level. Surprisingly, neither willingness to grow nor its interaction with innovativeness was significant. This leads to the conclusion that Hypothesis 1 is weakly supported, but that Hypothesis 2 is not supported in the sample as a whole. When we added in the factorial interactions with age class, an interesting observation can be made. While the interaction between innovativeness and willingness to grow remains nonsignificant, we can see that the effect of innovativeness on internationalization is significant only for young firms. Hence we can conclude that Hypothesis 3 (The effect of innovativeness is stronger for younger firms) is supported, but that Hypothesis 4 (The interaction between innovativeness and willingness to grow is stronger for younger firms) is not.

\section{DISCUSSION AND CONCLUSIONS}

In this study, we analyzed the effects of innovativeness on internationalization at the firm level, using data from a longitudinal survey of the Finnish software industry. The results indicate that innovativeness is indeed positively related to software firm internationalization. This finding is in line with INV theory [34] and with earlier studies on born globals and INVs $[8,22]$. However, a somewhat unexpected finding was that the relationship between innovativeness and internationalization is not moderated by willingness to grow. The findings here indicate that the effect of innovativeness is stronger for younger firms, becoming nonsignificant for older firms. There are several possible explanations for this tendency. First of all, it is possible that innovativeness only helps younger firms, whereas internationally well established firms may use other resources for internationalization [19, 20]. A second possibility is that because innovative firms seem to internationalize earlier than their less innovative counterparts, a large proportion of these firms are already international at a later age. Since the firms are already international, the measure of internationalization used in this study does not capture any further international expansion.

The age categorization data in Table 2 also shows that the strongest correlation between international revenue and innovativeness exists for firms younger than two years; this could indicate that a new innovative offering is an effective means of penetrating the international markets. The correlation between international revenue and willingness to grow is strongest for firms aged 2-5 years, while the youngest international firms seem to have smaller growth orientation attitude. This seems to be in line with the INV theory, which describes firms that are international from their inception - firms which emphasize growth and profitability only after they have established a presence in international markets.

These observations suggest that further studies could apply clustering methods for extracting archetypes of internationalization behavior from the data sets in question. However, in our case, a set of 214 firms with a mean age of 1.7 years necessarily sets some limits on approaches of this kind, with respect to the later phases of internationalizing behavior.

This study, like all other studies, is not without weaknesses. The greatest problem in the research design is how to measure innovativeness. Although self-reporting scales do not share the same weaknesses as patent data or R\&D intensity, self-reports are subject to other kinds of 


\section{$3^{\text {rd }}$ International Conference on Research and Innovation in Information Systems - 2013 (ICRIIS'13)}

measurement error [38]. Moreover, the binary variable measuring internationalization might not have sufficient fidelity to capture the phenomenon. It is quite possible that the firms in question are merely experimenting with internationalization, and that they never achieve international breakthrough. However, this is not captured in the measure we used.

\section{REFERENCES}

[1] Achen, C. H. Why lagged dependent variables can suppress the explanatory power of other independent variables. In Annual Meeting of the Political Methodology Section of the American Political Science Association, UCLA (pp. 20-22), (2000)

[2] Autio, E., Miikkulainen, K., Sihvola, I. Innovatiiviset kasvuyritykset (Teknologiakatsaus No. 201/2007) (p. 50). Helsinki: Tekes. (2007)

[3] Autio, E., Sapienza, H. J., Almeida, J. G. Effects of Age at Entry, Knowledge Intensity, and Imitability on International Growth. The Academy of Management Journal, 43(5), 909-924 (2000)

[4] Barney, J. Firm Resources and Sustained Competitive Advantage. Journal of Management, 17(1), 99-120 (1991)

[5] Bartel, A., Ichniowski, C., Shaw, K. How Does Information Technology Affect Productivity? Plant-Level Comparisons of Product Innovation, Process Improvement, and Worker Skills. Quarterly Journal of Economics, 122(4), 1721-1758 (2007)

[6] Bell, J. The internationalization of small computer software firms. European Journal of Marketing, 29(8), 60-75 (1995).

[7] Bell, J., McNaughton, R., Young, S., Crick, D. Towards an Integrative Model of Small Firm Internationalisation. Journal of International Entrepreneurship, 1(4), 339-362 (2003)

[8] Bell, J., Crick, D., Young, S. Small Firm Internationalization and Business Strategy: An Exploratory Study of 'KnowledgeIntensive' and 'Traditional' Manufacturing Firms in the UK. International Small Business Journal, 22(1), 23-56 (2004)

[9] Boter, H., Holmquist, C. Industry characteristics and internationalization processes in small firms. Journal of Business Venturing, 11(6), 471-487 (1996).

[10] Brynjolfsson, E. The productivity paradox of information technology. Commun. ACM, 36(12), 66-77 (1993)

[11] Carden, S. D., Mendonca, L. T., Shavers, T. What global executives think about growth and risk. McKinsey Quarterly, 2, 16-25 (2005)

[12] Chetty, S.K., Stangl, L.M. Internationalization and innovation in a network relationship context. European Journal of Marketing, 44(11/12), 1725-1743 (2010)

[13] Coad, A., Rao, R. Innovation and firm growth in high-tech sectors: A quantile regression approach. Research Policy, 37(4), 633-648 (2008)

[14] Coviello, N. The network dynamics of international new ventures. Journal of International Business Studies, 37(5), 713731 (2006)

[15] Coviello, N., Munro, H. Network Relationships and the Internationalisation Process of Small Software Firms. International Business Review, 6(4), 361-386 (1997)

[16] Covin, J. G., Slevin, D. P. Strategic management of small firms in hostile and benign environments. Strategic Management Journal, 10(1), 75-87 (1989)

[17] Dillman, D. A. Mail and internet surveys: The tailored design method. New Jersey: John Wiley \& Sons, Inc. (2007)

[18] Freel, M. S. Do Small Innovating Firms Outperform NonInnovators? Small Business Economics, 14(3), 195-210 (2000)
[19] Johanson, J., Vahlne, J. The Internationalization Process of the Firm: A Model of Knowledge Development and Increasing Foreign Market Commitments. Journal of International Business Studies, 8(1), 23-32 (1977)

[20] Johanson, J., Vahlne, J. The Uppsala internationalization process model revisited: From liability of foreignness to liability of outsidership. Journal of International Business Studies, 40(9), 1411-1431 (2009)

[21] Johanson, J., Wiedersheim-Paul, F. The internationalization of the firm: four Swedish cases. Journal of Management Studies, 12 (3), 305-322 (1975)

[22] Knight, G. A., Cavusgil, S. T. Innovation, Organizational Capabilities, and the Born-Global Firm. Journal of International Business Studies, 35(2), 124-141 (2004)

[23] Kontinen, T., Ojala. A. Internationalization pathways among family-owned SMEs. International Marketing Review, 29 (5), 496-518 (2012)

[24] Kontio, J., Rönkkö, M., Mutanen, O., Ahokas, M., Junna, O., Ali-Yrkkö, J., Touru, A., et al. Kasvufoorumi 08. Helsinki: Ohjelmistoyrittäjät ry. Retrieved from http://www.ohjelmistoyrittajat.fi/files/documents/kasvufoorumi 08_loppuraportti.pdf (2008)

[25] Kreiser, P. M., Marino, L. D., Weaver, K. M. Assessing the Psychometric Properties of the Entrepreneurial Orientation Scale: A Multi-Country Analysis. Entrepreneurship: Theory \& Practice, 26(4) (2002)

[26] Kuivalainen, O., Saarenketo, S. International Pathways of Software Born Globals, in Gabrielsson, M. and Kirpalani, M.V.H. (Eds): Handbook of Research on Born Globals. Cheltenham, UK and Northampton, MA, USA: Edward Elgar Publishing. (2012)

[27] Lopez, L.E., Kundu, S., Ciravegna, L. Born global or born regional? an from an exploratory study in the Costa Rican software industry. Journal of International Business Studies, 40(7), 1228-1238 (2009)

[28] McDougall, P., Shane, S., Oviatt, B.M. Explaining the formation of international new ventures: The limits of theories from international business research. Journal of Business Venturing, 9(6), 469-487 (1994)

[29] Moen, O., Gavlen, M., Endresen, I. Internationalization of small, computer software firms: Entry forms and market selection. European Journal of Marketing, 38(9-10), 1236-1251 (2004)

[30] Nambisan, S. Software firm evolution and innovationorientation. Journal of Engineering and Technology Management, 19(2), 141-165 (2002)

[31] Ojala, A. Entry in a Psychically Distant Market: Finnish Small and Medium-sized Software Firms in Japan. European Management Journal, 26(2), 135-144 (2008)

[32] Ojala, A., Tyrväinen, P. Market Entry and Priority of Small and Medium-Sized Enterprises in the Software Industry: An Empirical Analysis of Cultural Distance, Geographic Distance, and Market Size. Journal of International Marketing, 15(3), 123-149 (2007)

[33] Ojala, A., Tyrväinen, P. Market entry decisions of US small and medium-sized software firms. Management Decision, 46(2), 187-200 (2008)

[34] Oviatt, B.M., McDougall, P.P. Toward a Theory of International New Ventures. Journal of International Business Studies, 25(1), 45-64 (1994)

[35] Pavitt, K. Patent statistics as indicators of innovative activities: Possibilities and problems. Scientometrics, 7(1-2), 77-99 (1985) 
[36] Peltonen, J., Rönkkö, M. Effects of Board Size and Board Interlocks on International Expansion of High-Technology Ventures. Presented at the The 30th SMS Annual International Conference, Rome, Italy. (2010)

[37] Pla-Barber, J., Alegre, J. Analysing the link between export intensity, innovation and firm size in a science-based industry. International Business Review, 16(3), 275-293 (2007)

[38] Podsakoff, P.M., Organ, D.W. Self-Reports in Organizational Research: Problems and Prospects. Journal of Management, 12(4), 531-544 (1986)

[39] Rönkkö, M., Mutanen, O., Koivisto, N., Ylitalo, J., Peltonen, J., Touru, A., Hyrynsalmi, S., et al. National Software Industry Survey 2008. Espoo, Finland: Helsinki University of Technology. Retrieved from http://www.softwareindustrysurvey.org/report2008.pdf (2009)

[40] Rönkkö, M., Peltonen, J. Internationalization of Software Firms - Evidence from Finland. Presented at the The First International Conference on Software Business (ICSOB), Jyväskylä, Finland. (2010)

[41] Smith, K.H. Measuring innovation. In: The Oxford Handbook of Innovation. Oxford University Press, New York, US, pp. 148-177. (2005)

[43] Terjesen, S., O'Gorman, C., Acs, Z.J. Intermediated mode of internationalization: new software ventures in Ireland and India. Entrepreneurship \& Regional Development, 20(1), 89-109 (2008) 